\title{
A review of the long-term effects of prazosin and hydralazine in chronic congestive heart failure
}

\author{
W. RUTISHAUSER \\ Center of Cardiolog.y. University Hospital. \\ Geneva, Switzerland
}

KEY WORDS: Congestive heart failure, prazosin, hydralazine.

In the last two years, six studies using prazosin in doses of $3-32 \mathrm{mg} /$ day for two and 16 months have shown a persistent but variable benefit in $50-80 \%$ of those who initially responded favorably. However, serious side-effects occurred in up to $40 \%$ and in many cases, tolerance developed. Mortality was 25-38\% in 3-6 months, $50 \%$ by one year.

In five studies using hydralazine (sometimes combined with long acting nitrates), 150 patients observed from six up to 29 months showed sustained benefit in 26 to 59\%, while in many cases hemodynamic values returned to pretreatment values. Again side-effects were considerable, with worsening of angina, fluid retention, gastrointestinal symptomatology and, rarely. lupus erythematodes. Mortality was $28-41 \%$ in $10-12$ months, higher in non-responders than in responders.

Although exercise capacity increased in responders, no data are available today to prove that these vasodilators allow heart failure patients to live longer. Prudence is indicated in patients with congestive heart failure due to coronary artery disease. Furthermore, tolerance development, which only may be surmountable if discontinuation for a few weeks or switching to another drug is possible, is a serious problem limiting chronic vasodilator application.

Heart failure is a state of abnormal cardiovascular regulation in which the afterload mismatch is of major importance(1), fundamental compensatory changes having led to an increase in peripheral vascular resistance and an increase in heart size. Early treatment by vasodilators would therefore delay, or might even prevent heart failure: arterial dilatation would lead to a better unloading of the ventricle during systole, providing an increased muscle shortening (1); venous dilatation together with increased ventricular emptying would favor a decrease in end-diastolic heart size ${ }^{(2)}$. This attractive hypothesis has been tested in congestive heart failure and found to be true in several acute studies ${ }^{(3-5)}$.

For vasodilators to be effective in chronic heart failure, the beneficial acute hemodynamic actions of these agents should be maintained in long-term treatment. An increase in exercise capacity or the same exercise with more favorable hemodynamic parameters is an important long-term goal. Optimally

Requests for reprinis to Prof W Rutıshauser. Center of Cardıology, University Hospital. CH-1211 Geneva 4. Switzerland one would like naturally to see reduced morbidity and mortality. Finally, these goals should be achieved without major adverse side-effects.

This presentation reviews the results of treatment with prazosin and hydralazine administered for several months to patients in chronic heart failure. Prazosin is mainly a postsynaptic alpha-adrenergic blocker $^{(6)}$. It increases cardiac output and stroke volume significantly during exercise and to a lesser degree at rest, alpha-adrenergic blockade being more evident during exercise ${ }^{(7)}$.

Recently, four studies have been reported using prazosin in doses of 3-32 mg/day for 6-16 months and involving 68 patients $\mathrm{s}^{(8-11)}$; in two further studies treatment was only assessed for 2-3 months ${ }^{(12-13)}$. All patients were in heart failure and treated continuously with digitalis and diuretics. Table I gives details about the observed beneficial and sideeffects in these studies and their mortality.

Depending on the underlying degree of heart failure and the level of sympathetic tone, the results of the initial therapy may vary considerably. The 
Table I Recent long-term prazosin studies in patients with chronc congestive heart fallure

\begin{tabular}{|c|c|c|c|c|c|c|c|}
\hline & \multirow[t]{2}{*}{ Months } & \multirow[t]{2}{*}{$\mathrm{n}$} & \multirow[t]{2}{*}{$\begin{array}{l}\text { Dosage } \\
(\mathrm{mg} / \text { day })\end{array}$} & \multirow[t]{2}{*}{ Beneficial effects } & \multirow[t]{2}{*}{ Side-effecs } & \multicolumn{2}{|l|}{ Mortality at } \\
\hline & & & & & & $\begin{array}{cc}2-3 & 6 \\
& \text { months }\end{array}$ & 12 \\
\hline Rouleau et $a l^{(8)}$ & 159 & 34 & $3-21$ & $\begin{array}{l}\text { If spironolactone added } \\
\text { good long-term effects }\end{array}$ & $\begin{array}{l}\text { Spironolactone prevents } \\
\text { attenuation }\end{array}$ & & $50 \%$ \\
\hline Awan el $a l^{(9)}$ & 12 & 16 & $8-32$ & $\begin{array}{l}\text { NYHA } \overline{4} \rightarrow \overline{2 \cdot 5} \text {, persistent } \\
\text { symptomatic benefit }\end{array}$ & Delayed tolerance in $30 \%$ & Not mentioned & \\
\hline Kuck et al. ${ }^{(10)}$ & 6 & 10 & 15-20 & $\begin{array}{l}\text { SVR during exercise and } \\
\text { PAP at rest and exercise } \\
P<0.05\end{array}$ & $\begin{array}{l}\text { Hypotension in } 40 \% \\
\text { tendency to fluid retention }\end{array}$ & Not mentioned & \\
\hline Bertel et al. (11) & 6 & 8 & $3-20$ & $\begin{array}{l}\mathrm{CI} \text { and } \mathrm{SVI} \text { at rest } \\
P<0.05 \text { exercise tolerance }\end{array}$ & Orthostatic dizziness in $8 \%$ & $25 \%$ & \\
\hline $\begin{array}{l}\text { Feldman et al }{ }^{(12)} \\
\text { Colueci et al. }{ }^{(13)} \\
\text { Randomized double- } \\
\text { blind }\end{array}$ & $\begin{array}{l}3 \\
2\end{array}$ & $\begin{array}{l}13 \\
10\end{array}$ & $\stackrel{5}{16-24}$ & $\begin{array}{l}\text { improved } \\
\text { NYHA } 3.7 \rightarrow 2 \cdot 3 \text {, exercise } \\
\text { duration and EF } P<0.01\end{array}$ & $\begin{array}{l}\text { In } 30 \% \text { deterioration } \\
\text { Increased diuretics } \\
\text { necessary }\end{array}$ & $\begin{array}{l}38 \% \\
\text { Praz. } 0 \% \\
\text { Pbo. } 17 \%\end{array}$ & \\
\hline
\end{tabular}

$\mathrm{Cl}=$ cardiac index; $\mathrm{EF}=$ ejection fraction; $\mathrm{NYHA}=\mathrm{New}$ York Heart Association classification; PAP $=$ mean pulmonary artery pressure: Pbo. = placebo; Praz. = prazosın: SVI = stroke volume index. SVR = systemic vascular resistance.

response to long-term therapy with prazosin depends even more on the underlying cause and severity of heart failure. Only in a subset of patients did a sustained beneficial effect persist, mainly during exercise. The phenomenon of tolerance was observed in most studies. The addition of spironolactone or an increase of other diuretics may prevent attentuation.

Hydralazine has potent direct arteriolar dilatator effect. In five recent studies using hydralazine (mostly in doses up to $400 \mathrm{mg} /$ day) a total of 150 patients were observed for six to 29 months ${ }^{(14-19)}$. A bout $20 \%$ were considered early non-responders and about the same percentage stopped therapy because of sideeffects. The main positive effects, as well as the considerable adverse effects and the mortality of these studies are summarized in Table 2 . In these

Table 2 Recent long-term hydralazine and mutrate studies in patient with chronic congestive failure

\begin{tabular}{|c|c|c|c|c|c|c|c|c|}
\hline & \multirow[t]{2}{*}{ Months } & \multirow[t]{2}{*}{$\mathrm{n}$} & \multirow{2}{*}{$\begin{array}{l}\text { Dosage } \\
\text { (mg/day) }\end{array}$} & \multirow[t]{2}{*}{ Beneficial effects } & \multirow[t]{2}{*}{ Side-effects } & \multicolumn{3}{|c|}{ Mortality at } \\
\hline & & & & & & 6 & $\begin{array}{l}12 \\
\text { month }\end{array}$ & $\mathrm{s}^{18}$ \\
\hline Morand et $a l^{(1 \triangleleft)}(\mathrm{H})$ & 29 & 37 & $200-400$ & $\begin{array}{l}\text { CI increased initially } \\
80 \% * \text { later less difference }\end{array}$ & $\begin{array}{l}\text { Nausea, headaches, only } \\
\text { first month. } 13 \% \\
\text { antınuclear antibodies }\end{array}$ & $32 \%$ & $41 \%$ & $\begin{array}{l}>\text { in } \\
\text { IHD }\end{array}$ \\
\hline Massie et $a l^{(15)}(\mathrm{H}+\mathrm{N})$ & 13 & 56 & $<400$ & $\begin{array}{l}59 \% \text { improvement by } \\
\text { NYHA-classes in } 6 \\
\text { months }\end{array}$ & $\begin{array}{l}\text { Gastro-intestinal } 32 \% \text {, } \\
\text { headache } 14 \% \\
18 \% \text { stopped therapy, } \\
5 \% \text { systemic lupus } \\
\text { erythematodes }\end{array}$ & $22 \%$ & $37 \%$ & $63 \%$ \\
\hline Walsh et al. ${ }^{(16)}(\mathrm{H}+\mathrm{N})$ & 10 & 34 & & $\begin{array}{l}50 \% \text { of patients main- } \\
\text { tained on therapy have } \\
\text { sustained benefit }\end{array}$ & $\begin{array}{l}21 \% \text { early non-responders. } \\
24 \% \text { stop because side- } \\
\text { effects }\end{array}$ & & $\begin{array}{r}0 \% \\
87 \%\end{array}$ & $\begin{array}{l}\text { R } \\
\text { NR }\end{array}$ \\
\hline Packer et al..$^{(17)}(\mathrm{H})$ & $8 \cdot 6$ & 11 & Up to 900 & & & Not m & Ientione & \\
\hline Mathey ef $a l^{(18)}(\mathrm{H})$ & 6 & 12 & $100-300$ & $\begin{array}{l}6 \text { months: } \mathrm{Cl}+59 \% \\
\text { renal plasma flow }+35 \%\end{array}$ & & Not $\mathrm{m}$ & entione & \\
\hline
\end{tabular}

$\mathrm{CI}=$ cardiac index $; \mathrm{IHD}=$ ischemic heart disease; $\mathrm{NR}=$ non-responders, $\mathrm{NYHA}=$ New York Heart Association;

$\mathbf{R}=$ responders; $\mathrm{H}=$ hydralazine; $\mathrm{N}=$ nitrates.

$P<0.05$. 
studies, too, the pronounced initial hemodynamic effect was attenuated in most patients with time and benefit was sustained in only about half of those patients maintained on therapy.

A tendency toward higher mortality is reported in patients with heart failure due to coronary heart disease $^{(14,15)}$. The effect on the coronary circulation has to be considered. Reduced diastolic aortic pressure means a generally reduced coronary perfusion pressure. Therefore the flow through fixed coronary stenoses decreases. A coronary steal phenomenon can take place, leading to lactate production $^{(19)}$.

\section{Discussion}

Even with vasodilators which have differing molecular mechanisms and effects on regional flow, the main problem in long-term use is an attenuation of the desired effect in a high percentage of patients ${ }^{(20)}$. It is at the present not clear which subsets of patients receive the greatest profit from a given vasodilator. In severe heart failure with markedly increased plasma levels of norepinephrine, but not necessarily always increased renin-angiotensin, the application of prazosin has been thought to be most favorable. But a reduction of sympathetic activity could be counteracted by the release of preformed norepinephrine with no net effect on plasma norepinephrine levels ${ }^{(21)}$. Furthermore the changes in receptor sensitivity as documented, e.g. by the blunted baroreceptor reflex in heart failure, may be more important than the plasma level of a hormone.

Also since the sympathetic nervous system and the renin-angiotensin system may be activated independently in congestive heart failure, it is understandable that inhibition of one system may not give the desired response because of compensation by the other ${ }^{(22)}$. This reason may explain the fact that the reaction to both prazosin and hydralazine in chronic congestive failure varies, and that the chronic effects are less evident than the acute.

\section{References}

(1) Pouleur H. Covell JW, Ross J Jr. Effects of alterations in aortic input impedance on the force-velocity-length relationship in the intact canine heart. Circ Res 1979 45: 126-36.

(2) Pouleur H, Covell J, Ross J Jr. Effects of nitroprusside on venous retum and central blood volume in the absence and presence of acute heart falure. Circulation $1980 ; 61 \cdot 328-37$.
(3) Chatterjee K. Parmley WW, Ganz W, el al Vasodilating drugs in acute myocardal infarction. Circulation 1973; 48: 1183-93.

(4) Cohn, JN, Franciosa JA. Vasodilator therapy of cardiac failure. N Engl J Med 1977; 297: 27-31. 2548.

(5) Miller RR, Viasmara LA. Williams DO, Amsterdam EA, Mason DT. Pharmacological mechanisms for left ventricular unloading in clinical congestive heart falure. Circ Res 1976; 39: 127-33.

(6) Graham RM, Pettinger WA. Drug therapy: prazosin. N Engl J Med 1979, 300: 232.

(7) Rubin SA, Chatterjee K. Gelberg HJ. Paradox of improved exercise but not resting hemodynamics with short-term prazosin in chronic heart failure. Am J Cardiol 1979; 43: 810-5.

(8) Rouleau JL, Warnica JW, Burgess JH. Prazosin and congestive heart failure: short-and long-term therapy. Am J Med 1981; 71 . 147-52.

(9) Awan NA. Needham KE. Evenson MK, Amsterdam EE, Mason DT. Therapeutic application of prazosin in chronic refractory congestive heart failure. Am J Med 1981: 71: 153-60.

(10) Kuck KH, Hanrath P. Zenke A, Mathey D, Bleifeld W. Haemodynamic effects of long-term prazosin therapy in patients with congestuve heart failure. J Cardiovasc Pharmacol 1980; 2 (suppl 3): S427-41.

(11) Bertel O, Burkart F, Bühler FR. Sustained effectiveness of chronic prazosin therapy in severe chronic congestive heart failure. Am Heart J 1981: $101: 529-33$

(12) Feldman RC, Ball RM, Winchester MA, Jaillon P, Kates RE, Harrison DC. Beneficial hemodynamic response to chronic prazosin therapy in congestive heart failure. Am Heart J 1981; 101 : 534-40.

(13) Colucci WS, Wynne J, Holman BL. Braunwald E. Long-term therapy of heart failure with prazosin: a randomized double blınd trial. Am J Cardiol 1980; 45: $337-44$.

(14) Morand P, Masson D. Lavigne G. The long-term effects of dihydralazine in chronic heart failure. In: Rutishauser $W$, ed. The place of vasodilators in the long-term treatment of intractable heart failure. Bern: Huber, 1981: 30-40 (and unpublished follow-up).

(15) Massie B, Ports T, Chatterjee K. el al. Long-term vasodilator therapy for heart failure: clinical response and its relationship to hemodynamic measurements. Circulation 1981, 63: 269-78.

(16) Walsh WF, Greenberg BH. Results of long-term vasodilator therapy in patients with refractory congestive heart failure. Circulation 1981: 64: 499-505.

(17) Packer M, Meller J. Medina N. Yushak M, Gorlin R. Hemodynamic characterization of tolerance to longterm hydralazıne therapy in severe chronic heart failure. N Engl J Med 1982; 306: 57-62.

(18) Mathey D, Hanrath P, Polster J, Witte G, Montz R. Bleifeld W. Short and long-term effects of hydralazine on left ventricular pump function and renal hemodynamics in chronic congestive heart failure. In: Rutishauser W, ed. The place of vasodilators in the long-term treatment of intractable heart failure. Bern: Huber, 1981: 23-8.

(19) Rouleau JL, Chatterjee K. Benge W. Parmley WW. 
Hiramatsu B. Alterations in left ventricular function and coronary hemodynamics with captopril, hydralazine and prazosin in chronic ischemic heart failure: a comparative study. Circulation 1982; 65: 671-8.

(20) Colucei WS, Williams GH, Alexander RW. Braunwald E. Mechanisms and implications of vasodilator tolerance in the treatment of congestive heart failure. Am J Med 1981, 71: 89-99.

(21) Kluger J, Cody RJ, Laragh JH. The contributions of sympathetic tone and the renin-angiotensin system to severe chronic congestive heart failure: response to specific inhibitors (prazosin and captopril). Am J Cardiol 1982; 49: 1667-74.

(22) Levine TB, Francis GS, Goldsmith SR, Simon AB, Cohn JN. Activity of the sympathetic nervous system and renin-angiotensin system assessed by plasma hormone levels and their relation to hemodynamic abnormalities in congestive heart failure. Am J Cardiol $1982 ; 49: 1659-66$. 